\title{
流れの中の風波の研究 (2)
}

\section{1. まえがき}

潮流などの流れがある海では，風と流れの向きの順・ 逆により海面状態すなわち波が著しく変化することが昔 から船乗りなどの間では知られていた。事実，風洞水槽 で流れの上に風を吹かせた場合，本文で示すように小さ な流れでも風波の発生・発達に大きな影響をおよぼす。 このような流れの影響は通常比較的短いフェッチに限ら れるが，河口や海峡などの流れの大きい場所での風波の 推算を試みる場合には無視できないであるう。しかるに 従来から使われている波の推算法でも, 最近の風波の発 達理論でも，水中の流れは全く無視されていて，簡単に 流れの効果を算定する方法は見当らない。一方，流れの 中の風波安実駼的飞調べた研究も㐫りなく，著者らの 知るところこれまでに発表されているのは Francis ら と加藤・佐野2)くらいである。

上記の第 1 報 2 では，流れの中の風波の実験における 波数スペクトルに代るものとして真のスペクトルの概念 を導入し，逆流のケースについての実駼結果から，真の スペクトルの計算を試みた。このスペクトル変換のため には流速分布に対応した波速，特に吹送流汶対する波速 の計算が必要で，第 1 報での直線分布を改良した放物線 分布に対する波速の計算も行った ${ }^{3)}$ 。との後吹送流の分 布は対数分布に近いという結果が Shemdin ${ }^{4)}$ や Dobroklonsky ら5)によって発表された。著者らの)もとれを実 験で確認するとともに，対数分布の吹送流に対する波速 定 1 次近似まで求め, また 2 本の波高計堂用いて風波の 成分波の波速を測定して計算値と比較した。この対数分 布に対する波速は，精度を上げるためとの後第 2 次近似 まで計算されている7)。

著者らは最初に述べた流れが風波の発生・発達におよ ぼす影響を調べるため，風洞水路を使って順流および逆 流の実験を行っているが，今回の論文では主として順流 のケースでの実験結果について述べる。今回も波の測定 結果から直接光られるのは見かけのスペクトルである が，それから真のスペクトルを計算することによりいく つかの発生波の特性と順流の影響を調べる。
加 藤 始*. 鶴 谷 広 一*

\section{2. 実験および解析方法}

\section{(1) 実 験 概 要}

実験は港湾技研の水循環装置付き風洞水路を使って行 った。測定部は幅 $1.5 \mathrm{~m}$ ，高さ $1.3 \mathrm{~m}$ で長さは $28.5 \mathrm{~m}$ あり (図一1 参照)，その風下で水路は $5.0 \mathrm{~m}$ まで拡幅 しながらさらに $18.0 \mathrm{~m}$ 延びており，その風下端にある 砂利とステンレスくず製の消波装置の下に水循環用の孔 あきパイプが設置されている。

流れの設定はベンチュリと流量調節バルブによって行 った。実験での流秃のケース法，順流の条件で（1）バ ルブ全開 $\left(Q_{\max } \fallingdotseq 224 l / \mathrm{sec}\right),(2)$ ベンチュリの差圧が $\Delta h=60.0 \mathrm{~cm}(Q \fallingdotseq 152 l / \mathrm{sec})$, ( 3 ) $\Delta h=15.0 \mathrm{~cm}$ および （4）流れなしの 4 ケースで, 水路での断面平均流速はそ れぞれ $\bar{U}=29.9 ， 20.3 ， 10.1$ および $0 \mathrm{~cm} / \mathrm{sec}$ に相当す る。

風速は送風機の回転数で設定しているが，実験での風 のケースは $\mathrm{rpm} 200$ と $\mathrm{rpm} 300$ の 2 ケースで，このと きの吹出口（A 点）での断面平均風速はとれぞれ $\bar{V} \fallingdotseq$

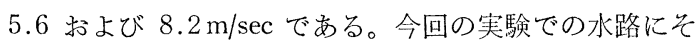
った測定点は 図一 1 に示した A-2，B，C，Dの 4 点 で，フェッチはとれぞれ $2.25 \mathrm{~m}, 9.75 \mathrm{~m}, 18.75 \mathrm{~m}$ ， $27.75 \mathrm{~m}$ である。

流れの測定は小型プロペラ流速計で行い，表面での吹 送流の大きさは紙のフロートを流して測定した。波の測 定は周波数応答性を考慮して抵抗線式波高計により，検 出部には $100 \mu$ の白金線（約 $2 \mathrm{~mm}$ 間隔）を使った。風 速は上記各点でピト一管と差理計を使って測定した。こ れらの風と波のデータは, 直接ディジタル・データレコ 一ダに記録し，計算機であとの処理を行った。

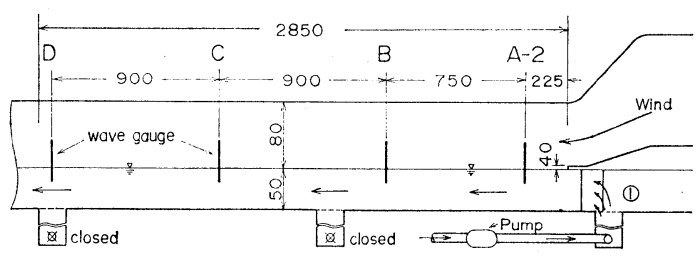

図一1 水路測定部見取図 


\section{（2）解析方法}

波のデータからはまず見かけの周波数 $f_{A}$ についての パワースペクトル $\phi_{A}\left(f_{A}\right)$ を計算する。次に吹送流と一 般流の測定結果をもとに真のスペクトル $\phi_{0}\left(f_{0}\right)$ を求め るが，それは次のような関係による。第 1 報2)に述べた ように真の周波数 $f_{0}$ とは波長 $L$ の波が静止した水中で もつ周波数と定義しており，静水中の波速を $c_{0}$ とする と次のように表わされる

$$
f_{0}=\frac{c_{0}}{L}=\frac{k}{2 \pi} \sqrt{\left(\frac{g}{k}+\frac{T_{1} k}{\rho}\right) \tanh k d}
$$

ここに， $k$ は波数， $T_{1}$ は表面張力， $d$ は水深である。 一方，ある流れの中での波長 $L$ の波の波速它 $c_{A}$ とする と，見かけの周波数 $f_{A}$ は次のように表わされる。

$$
f_{A}=c_{A} / L
$$

この $c_{A}$ の計算に当っては吹送流の影響を考慮しなけれ ばならないが，著者らはすでに吹送流が式 (3) の形の対 数分布でよく表わされることを示してそれに対する波速 它計算して扔り6),7，ここではとの結果索使う。すなわ ち吹送流の分布は次のように仮定する。

$$
U(y)=u_{0}-U_{r} \ln \left(\frac{z_{0}-y}{z_{0}}\right)-b y
$$

ここに, $z_{0_{w}}=0.01 \mathrm{~cm}$ とし $, u_{0}, U_{r}, b$ は実際の分布 に合せている。 $z_{0} w$ の值については, Keller ら ${ }^{8)}$ は (3) で $b=0$ とした分布形に対して実験結果から $z_{0_{w}} \fallingdotseq 0.3 / u_{0}$ の関係をえており，これはわれわれの rpm 300 の実験結 果とよく合っている。

流机の場に応じて波長 $L$ の関数として波速 $c_{A}$ 少計算 できれば（1）と（2）の関係から，流速分布に応じて $f_{0} \rightarrow$ $L \rightarrow f_{A}$ あるいはこの逆の計算ができる。波の方向分散 を無視すると，実験範囲でこの $f_{A}$ と $f_{0}$ は 1 対 1 に対 応するので, $\phi_{A}\left(f_{A}\right)$ と $\phi_{0}\left(f_{0}\right)$ の間には

$$
\phi_{0}\left(f_{0}\right)=\phi_{A}\left(f_{A}\right) \frac{\partial f_{A}}{\partial f_{0}}
$$

の関係があり，これを使って見かけのスペクトル $\phi_{A}$ か ら真のスペクトル $\phi_{0}$ を求めている。

\section{3. 実験結果とその考察}

流れなし，順流の $Q_{\max }$ および $Q_{60}(\Delta h=60 \mathrm{~cm}$ の意 味）の各ケースごとに各点の水路中央で測定した風速分 布より求めた $u_{*}$ の值冠表一1に示す。

幅方向流速分布の例として, 順流 $Q_{\max }, \operatorname{rpm} 300$ の ケースの A-2 点と C 点のものを 図一 2 に示す。図一 1 の (1) にある整流板と金網で調節したので A-2 点での水 面近くの分布は幅方向にほぼ一様であるが，C点あたり からは水面近くの分布で中央部が増大して幅方向の一様 性が悪くなり，これは改善できなかった。

波の測定は各ケース・各点ごとに，幅方向には中共 $(l=0)$ と中央より左と右に各 $50 \mathrm{~cm}(l=-50,+50 \mathrm{~cm})$
表一1 流れなしと順流のケースの $u_{*}$ の值 $(\mathrm{cm} / \mathrm{sec})$

\begin{tabular}{c|c|c|c|c|c|c}
\hline \multirow{2}{*}{ 測 点 } & \multicolumn{3}{|c|}{ rpm 200 } & \multicolumn{3}{c}{ rpm 300 } \\
\cline { 2 - 7 } & $Q_{\max }$ & $Q_{60}$ & $\bar{U}=0$ & $Q_{\max }$ & $Q_{60}$ & $\bar{U}=0$ \\
\hline A-2 & 19.1 & 19.7 & 21.9 & 34.8 & 34.3 & 38.8 \\
B & 23.5 & 24.2 & 26.1 & 30.3 & 35.3 & 43.5 \\
C & 19.6 & 20.5 & 24.5 & 27.9 & 31.3 & 37.0 \\
D & 18.0 & 20.0 & 24.9 & 26.3 & 28.5 & 41.8 \\
\hline
\end{tabular}

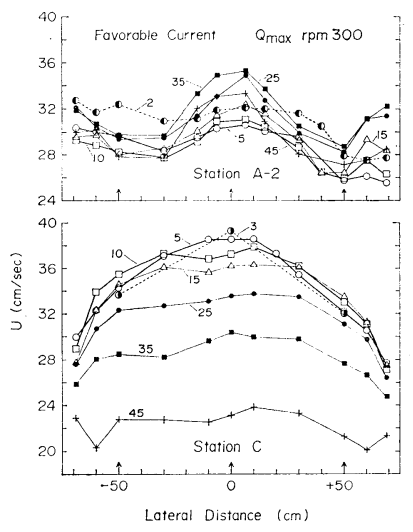

図一2 幅方向流速分布

の 3 点で測定している。流れなしと順流の $Q_{15}$ のケース では，各点とも $\sqrt{\overline{\eta^{2}}}$ は幅方向にほぼ一様であるが，順 流の $Q_{60}$ および $Q_{\max }$ のC点とD点では，中央 $(l=0)$ より $l= \pm 50 \mathrm{~cm}$ の值が相当大きく，その差は $\mathrm{D}$ 点では 30〜 40\% もあった。これは上に述べた流速分布の不均 一性によるものと思われる。

見かけのスペクトルの例として，順流 $Q_{\max }, \operatorname{rpm} 300$ のケースの各点中央 $(l=0)$ での結果を図一 3 に示す。 この図は通常の波の発達を示しているように見えるが， 流れの影響でピークはかなり高周波数側ヘシフトしてい

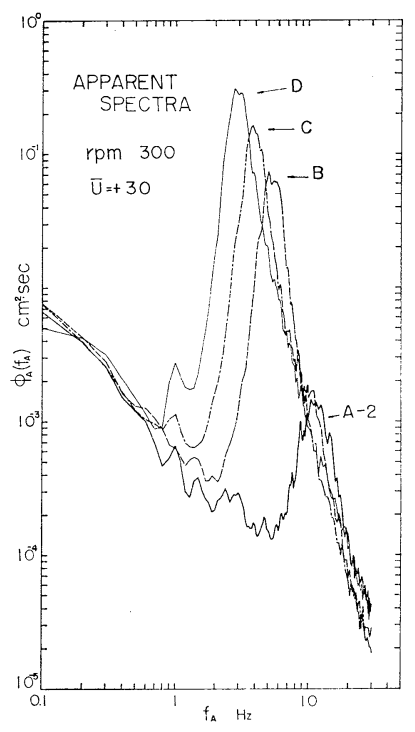

図一3 見かけのスペクトル 


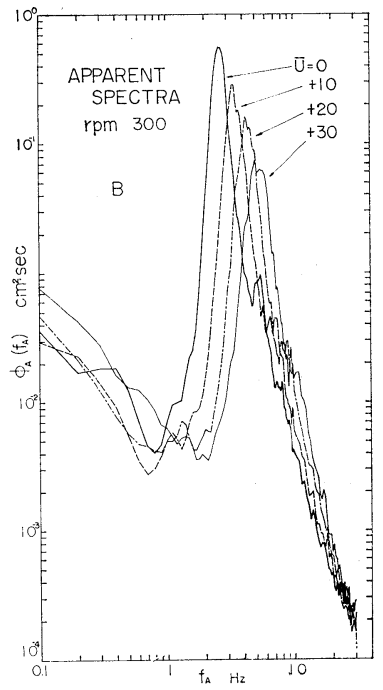

図一4見かけのスペクトル

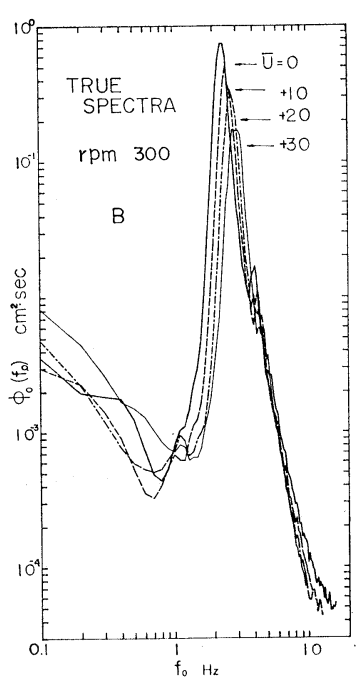

图一5 真のスペクトル

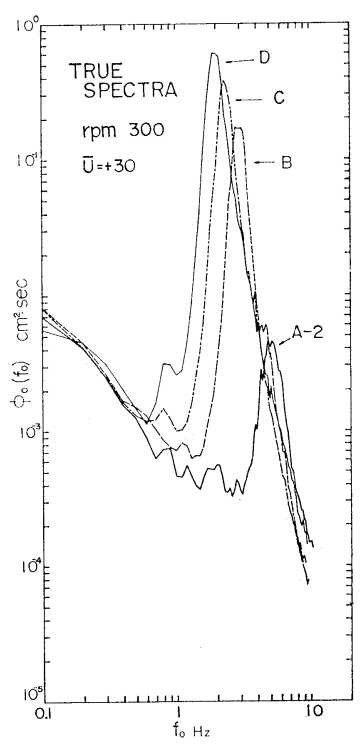

図一6 真のスペクトル

て，各成分波の変化を見るのには都合が悪い。たとえば 図一4 に示したのはフェッチ $18.75 \mathrm{~m}$ のB点で風は $\mathrm{rpm} 300$ で一定とし, 流れの条件だけを $\bar{U} \fallingdotseq 0,+10$, $+20,+30 \mathrm{~cm} / \mathrm{sec}$ と変えたときの見かけのスペクトル であるが，一見全く異なる波のように見える。しかしこ れら前述の方法で真のスペクトル $\phi_{0}\left(f_{0}\right)$ に変換する と図一5のようになり，一定のフェッチにおける別々の 流れの条件の下での波のスペクトルの高周波数領域がか なり似た変化をすることを示している。

図一3の見かけのスペクトルに対応する真のスペクト ルは図一6のようになる。この図から各成分波の発達の 様子が読取れるわけであるが，それをさらにわかりやす くするため, 各周波数 $f_{0}$ ごとにスペクトル密度のフェ ッチに対する変化をプロットしたのが図一7である。こ

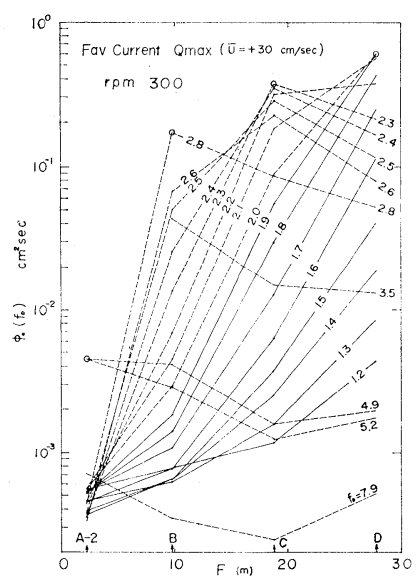

図一7 $\phi_{0}\left(f_{0}\right)$ の変化

表一2 各測点間での発達率 $a$ の值（rpm 300 の流れなしと順流の各ゲース，単位 $\mathrm{m}^{-1}$ )

\begin{tabular}{|c|c|c|c|c|c|c|c|c|c|c|c|c|}
\hline \multirow{2}{*}{$\begin{array}{c}\mathrm{f}_{0} \\
(\mathrm{~Hz})\end{array}$} & \multicolumn{3}{|c|}{$\bar{U}=0$} & \multicolumn{3}{|c|}{$\overline{\mathrm{U}} \fallingdotseq+10$} & \multicolumn{3}{|c|}{$\bar{U} \fallingdotseq+20$} & \multicolumn{3}{|c|}{$\bar{U} \fallingdotseq+30$} \\
\hline & $A \sim B$ & $\mathrm{~B} \sim \mathrm{C}$ & $\mathrm{C} \sim \mathrm{D}$ & $A \sim B$ & $\mathrm{~B} \sim \mathrm{C}$ & $C \sim D$ & $A \sim B$ & $\mathrm{~B} \sim \mathrm{C}$ & $C \sim D$ & $A \sim B$ & $B \sim C$ & $\mathrm{C} \sim \mathrm{D}$ \\
\hline 1.3 & 0.136 & 0.278 & 0.355 & 0.314 & 0.188 & 0.314 & 0.205 & 0.130 & 0.250 & 0.041 & 0.104 & 0.186 \\
\hline 1.4 & 0.165 & 0.359 & 0.351 & 0.346 & 0.240 & 0.388 & 0.183 & 0.171 & 0.312 & 0.068 & 0.149 & 0.223 \\
\hline 1.6 & 0.397 & 0.525 & 0.236 & 0.346 & 0.438 & 0.360 & 0.206 & 0.324 & 0.357 & 0.071 & 0.233 & 0.322 \\
\hline 1.7 & 0.536 & 0.539 & 0.123 & 0.372 & 0.502 & 0.277 & 0.225 & 0.419 & 0.315 & 0.097 & 0.274 & 0.330 \\
\hline 1.8 & 0.676 & 0.488 & 0.020 & 0.446 & 0.529 & 0.150 & 0.284 & 0.461 & 0.260 & 0.132 & 0.340 & 0.296 \\
\hline 2.0 & 0.850 & 0.263 & -0.115 & 0.617 & 0.448 & -0.056 & 0.449 & 0.483 & 0.056 & 0.220 & 0.379 & 0.214 \\
\hline 2.2 & 0.921 & -0.019 & -0.090 & 0.773 & 0.231 & -0.130 & 0.603 & 0.366 & -0.084 & 0.362 & 0.427 & 0.020 \\
\hline 2.5 & 0.851 & -0.195 & -0.042 & 0.949 & -0.127 & -0.070 & 0.861 & 0.008 & -0.083 & 0.653 & 0.193 & -0.102 \\
\hline 2.7 & 0.594 & -0.136 & 0.047 & 0.824 & -0.174 & -0.019 & 0.931 & -0.139 & -0.072 & 0.774 & 0.014 & -0.090 \\
\hline 3.1 & 0.153 & 0.022 & 0.061 & 0.535 & -0.102 & 0.075 & 0.743 & -0.195 & 0.041 & $0.83 \overline{0}$ & -0.188 & -0.010 \\
\hline
\end{tabular}


の図の各区間の直線の公配 $a$ ，すなわち

$$
a=(1 / \Delta x) \log \left[\dot{\phi}_{0 x_{1}+\Delta x}\left(f_{0}\right) / \dot{\phi}_{0 x_{1}}\left(f_{0}\right)\right]
$$

は各区間での波の発達率学表すが，rpm 300 の各ケース について計算した $a$ の值は表一2のようになる。この表 には，どこかの区間で $a$ が最大值をとる周波数 $f_{0}$ はす

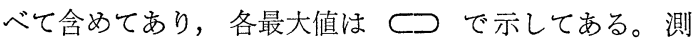
定点が 4 点しかないので, フェッチごとのこまかい变化 は見にくいが，図一7 および 表一2 から次のことがわか る。すなわち，特定の周波数について見ると，スペクト ル密度はフェッチの増加とともにはじめはゆるやかに発 達し，あるフェッチに達すると指数関数的な急激な発達 をし，その周波数がスペクトルのピークの位置を越える とともに発達が停止する。また各区間での発達率の最大 值は流れの条件の違いにより（ $Q_{\max }$ のケースがやや小 さいが）とれほど差はないが，流れが大きいほどその最 大值の生ずる周波数は大きく，したがってピークより下 の特定の周波数についてみると，流れが小さいほど $a$ の 值は大きくなっている。図一5 に示されたスペクトルの 高周波数領域の性質を考慮すると, $a_{\max }$ の生ずる周波数 の違いが，後で述べるような流れの条件により発生波の 大きさに差が出る原因と密接な関係があると思われる。

次に各ケースでの波の变化をみるため，スペクトルの 全パワー $\overline{\gamma_{i}^{2}}$ から 1 つのパラメーターとして $H_{1 / 3}$ を求 めて $l=0, \pm 50$ の 3 点平均值でプロットしたのが図一 8，9 である。両図には参考のため逆流の $Q_{15}$ と $Q_{60}$ の 2 ケースの結果 (点線) も示してある。そのうち $\bar{U} \fallingdotseq$ $-20 \mathrm{~cm} / \mathrm{sec}$ のケースでは第 1 報でも述べたようにフェ ッチう0 の点にも大きな波が生じ，A-2，B点あたりで は斜めに伝播する波長の長い波が存在するが，この現象 にはまだ不明な点があり，今回の論文では立入らない。 順流の各ケースでは流れだけによる水面変動分は補正し てあり，また $\bar{U} \fallingdotseq+20$ および $+30 \mathrm{~cm} / \mathrm{sec}$ のケースの C点とD点については，前述のように中央 $(l=0)$ だけ の波高は両図の值よりかなり小さくなる。それはとも かくとして，図一8, 9 の結果から順流が大きくなるほど

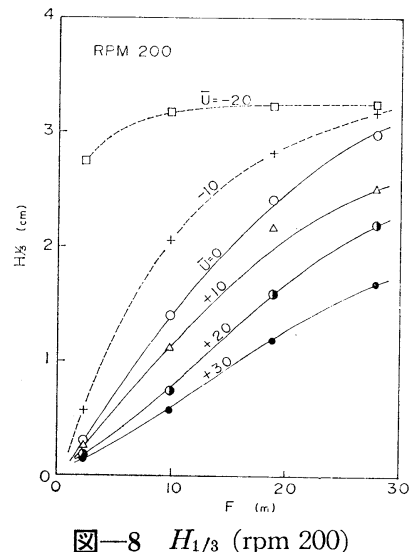

図-8 $\quad H_{1 / 3}(\operatorname{rpm~200)}$
各点の波が順次小さくなる様子がよくわかる。順流の各 ケース各点の $H_{1 / 3}(=\tilde{H})$ とその点の流れなしでの $H_{1 / 3}$ (= $\left.\tilde{H}_{0}\right)$ との比をとると図一10のようになるが，rpm 200 と 300 とで多少異なる傾向がみられる。同じ風速でも順 流が大きいほど波が小さくなる原因の 1 つには，表一1 に見られる $u_{*}$ の減少があるであろうが，それ以上に支 配的なのは流れが波のエネルギー伝達速度 $c_{E}$ 学増加さ せることではないかと思われる。もしそうであれば，フ ェッチが短かく波の波長が小さいときほど $\tilde{H} / \tilde{H}_{0}$ は小 さくなることが予想される。図一10で rpm 200 の A-2 点の結果はこれに反する傾向を示すが，この場合波は極 端に小さいので何か別の原因があるのかも知れない。

各点での卓越波の变化をみるため，スペクトルのピー ク $f_{m}$ に相当する波長定流速分布学考慮に入れて計算し た值 $L_{m}$ 定図一11 (rpm 200) と図一12(rpm 300) に

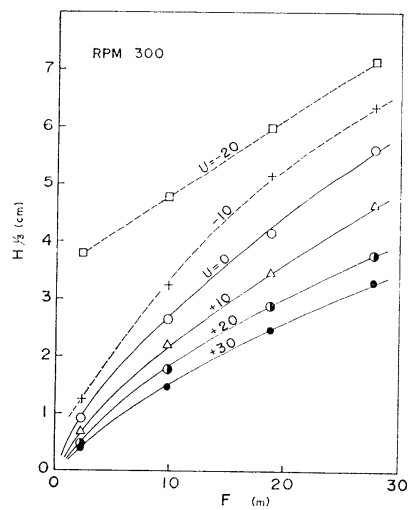

図-9 $H_{1 / 3}(\mathrm{rpm} 300)$

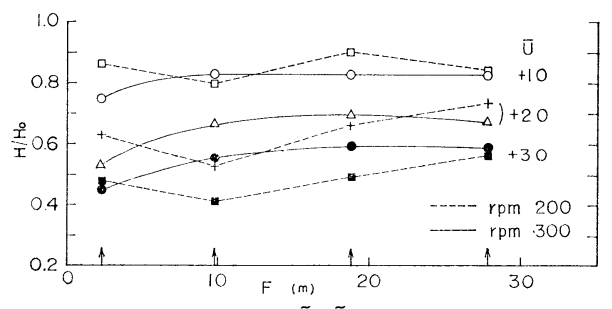

図-10 $\tilde{H} / \tilde{H}_{0}$ の值

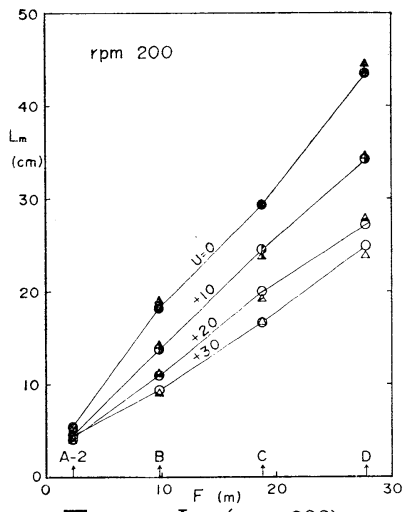

図一11 $L_{m}(\mathrm{rpm} 200)$ 
示す。両図には文献 6) で述べた 2 本の波高計の記録の クロス・スペクトルから求めた $\left(f_{m}\right.$ に対する) 波長 $L_{m}^{\prime}$ も示してあるが， $L_{m}$ と $L_{m}^{\prime}$ はかなりよく一致してい る。図-11, 12 から わかるように波長 $L_{m}$ は順流が大きい ケースほど各点とも 小さくなっている。 一般に流れのない場 所での発生波が順流 の中へ侵入したとき は，波高は減衰する が波長は増大する。 すなわち侵入波は, 波長に関して流れの 中での発生波とは全 く逆の性質を示すこ とは注意要要する。 Huang ら ${ }^{9)}$ 唯し

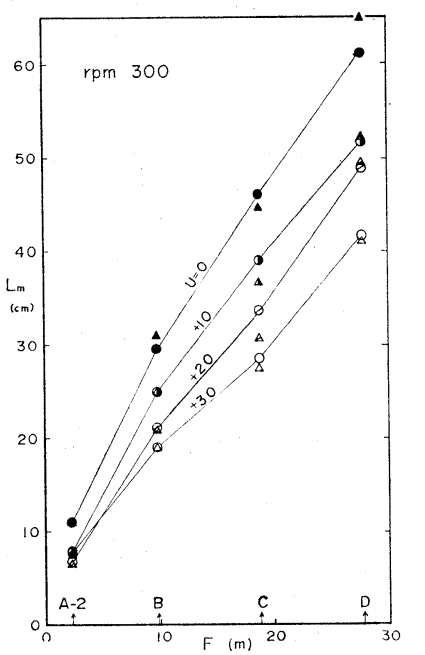

図-12 $L_{m}(\mathrm{rpm} 300)$
たように静水中で $\phi_{0}\left(f_{0}\right)$ のスペクトルをもつ波が一様 流速 $U_{1}$ の場所へ侵入したときのスペクトル $\phi_{A}\left(f_{A}\right)$ は 次式で表わされる $\left(f_{A}=f_{0}\right)$ 。

$$
\left.\begin{array}{l}
\phi_{A}\left(f_{A}\right)=4\left(1+R^{1 / 2}\right)^{-1} \cdot\left(R+R^{1 / 2}\right)^{-1} \cdot \phi_{0}\left(f_{0}\right) \\
R=1+\left(8 U_{1} \pi f_{0} / g\right)
\end{array}\right\}
$$

しかしながら，上に述べた ようにこの種の計算は流れ の中での発生波のスペクト ルの推定には使えない。実 際にどのように違うかを見 るために $\mathrm{rpm} 300$ で流れ なしのケースのC点(中央) での真のスペクトルをもと に, この波が $U_{1}=35.0$ $\mathrm{cm} / \mathrm{sec}$ の順流の中へ侵入 したときのスペクトル $\left(\phi_{A}\right)$ を式 (6) から求め，これを さらに真のスペクトルに変 換したものを図一13 の(1) (点線) に示す。同図には $\mathrm{rpm} 300$, 順流 $Q_{\max }$ のC点 (中央) での真のスペクト ルを(2)として示してある。吹送流の取扱いに多少不正 確さはあるが，(1) と（2) が全々別の波であること走す には十分と思われる。

\section{4. あとがき}

以上，順流の中での風波の実験結果について述べた。 順流が波の発達に拈よぼす影響について定量的な表現を らるには至らなかったが，真のスペクトルととれから求 めた各成分波の発達率を調べることにより，いくつかの 興味ある事実が見出された。今回の実験では測定点が 4 点で少なかったので，もっと多い実験を計画中である。

最後に，実験とデータ整理に協力して頂いた水理研究 窒の宮崎 豊, 土肥俊満両技官に深く感謝の意を表しま す。なお，データ処理と計算には港研計算センターの電 子計算機 TOSBAC-5600 を使用している。

\section{参 考 文 献}

1) Francis, J.R.D. and C.R. Dudgeon: An experimental study of wind-generated waves on a water current. Q.J. Roy. Met. Soc., Vol. 93, 247253, 1967.

2) 加藤 始・佐野喜久雄: 流れの中の風波について の研究 (1), 第 17 回海岸工学講演会論文集, 1924, 1970 .

3）加藤 始：放物線分布の吹送流に対する波速の計 算, 第 19 回海岸工学講演会論文集, 113-118, 1972.

4) Shemdin, O.H.: Wind-generated current and phase speed of wind waves. J. Phys. Oceanog., Vol. 2, 411-419, 1972.

5) Dobroklonsky, S.S. and B.M. Lesnikov: A study of near surface layer of drift currents in laboratory conditions. Izv. Acad. Sci., Atm. Oceanic Physics, Vol. 8, 1177-1187, 1972.

6）加藤 始 - 鶴谷広一：風波の成分波の波速につい $\tau$, 第21回海岸工学講演会諭文集, 255-259, 1974.

7）加藤 始：対数分布の吹送流に対する波速の計 算, 土木学会論文報告集, 第 239 号, 37-46, 1975.

8) Keller, W.C., T. R. Larson and J. W. Wright: Mean speeds of wind waves at short fetch., Radio Sci., Vol. 9, 1091-1100, 1974.

9) Huang, N.E., D.T. Chen and C.C. Tung: Interactions between steady non-uniform currents and gravity waves with applications for current measurements, J. Phys. Oceanog., Vol. 2, 420-431, 1972. 